\title{
Fraud Risk Assessment in Audit Planning in Internal Supervision Units: Case Study of Transportation Companies
}

\author{
Eka Septariana Puspa, Lufti Julian*
}

\author{
Magister of Accounting, Universitas Indonesia, Depok, Indonesia \\ *Corresponding author. Email: lufti.joelian@gmail.com
}

\begin{abstract}
The purpose of this study is to assess the maturity of PT X's fraud risk management program at the corporate level, compile a fraud risk assessment matrix by identifying possible fraud risk schemes, conduct fraud risk assessments (fraud risk assessment), and compile the Annual Supervision Work Program at the Sub Directorate of Internal Supervision Unit of PT X. This study uses quantitative and qualitative research (mix method) with descriptive research types. Primary data are obtained through observations and interviews with relevant officials to determine the maturity of fraud risk assessments, and secondary data are obtained through policy documents and internal company reports. The results of the study indicate that the maturity level of PT X's fraud risk management was 9.98 of 45 or 22.2\%. The fraud risk assessment identified 38 fraud risk schemes and a residual risk level consisting of 11 low-risk, 11 medium-risk, and 14 high-risk schemes. PT X's fraud risk assessment resulted in 11 internal supervision activities and 584 days of supervision that must be carried out within one year of supervision at the Head Office and Transbusway SBU.
\end{abstract}

Keywords: Fraud, Audit Intern, Fraud Risk Management, Fraud Risk Assessment

\section{INTRODUCTION}

Fraud as a financial crime is in the spotlight of the media and the public, both globally and in Indonesia. Fraud is measured annually by Transparency International in its report called the Corruption Perception Index (CPI). The CPI ranks countries based on a survey of perceptions of corruption in the public sector, including bribery activities for employees or state officials, corruption kickbacks on the procurement of goods and services, misuse of public funds, and the power to combat corruption in the public sector. Table I summarizes Indonesia's ranking in the CPI report.

Table I. Indonesia's Ranking in the CPI for 2010-2017

\begin{tabular}{|l|l|l|}
\hline Year & CPI Score & Rank \\
\hline 2012 & 3.2 & 118 of 174 \\
\hline 2013 & 3.2 & 114 of 175 \\
\hline
\end{tabular}

\begin{tabular}{|l|l|l|}
\hline 2014 & 3.4 & 107 of 174 \\
\hline 2015 & 3.6 & 88 of 167 \\
\hline 2016 & 3.7 & 90 of 176 \\
\hline 2017 & 3.7 & 96 of 180 \\
\hline
\end{tabular}

Table I shows that Indonesia's CPI values for the past eight years have increased, indicating decreasing corruption in Indonesia. This change could motivate for the Indonesian government to intensely eradicate corruption and fraud in Indonesia in both the public and commercial sectors.

In addition to the role of the Indonesian government, the role of businesspeople in minimizing fraud activities represents an effort to increase the value of Indonesia's CPI. Good businesspeople are not only oriented toward increasing profitability but also are aware of the importance of internal controls to manage every 
opportunity and threat that the company will face, both internal and external.

\section{THEORIES AND LITERATURE REVIEW}

\subsection{Internal Audit}

According to The Institute of Internal Auditors (2009), an internal audit is an independent, objective assurance and consulting activity that adds value to and improves an organization's operations. An internal audit assists an organization in accomplishing its objectives by bringing a systematic, disciplined approach to evaluating and improving the effectiveness of risk management, control, and governance processes.

The auditor's role and internal audit activities will develop over time. A measure of the success of an internal audit is not determined by the number of audit findings or the fulfillment of an annual audit plan but, rather, is determined by the benefits that management experiences regarding the existence of internal audit units within the organization. According to James (2000), the approach that can be carried out by the internal audit function to provide added value is to implement risk-based auditing, through which the auditor works with management to identify and assess business risks, focuses on major risks, and does not waste time controlling small risks.

\subsection{Fraud}

According to The Institute of Internal Audits (2009), fraud is any illegal action characterized by deception, concealment, or violations of trust and that is committed by individuals or organizations to gain personal and business benefits.

Fraud represents a disgrace of the victim and is something that must be hidden. One fact is that actual and total fraud will never be acknowledged because fraud becomes widely known as a result of reports to the authorities.

One element of the occurrence of fraud is the presence of victims who suffer losses; conversely, parties exist who obtain benefits in the form of money, property, or other economic benefits. The losses suffered by the victims represent the impacts of the fraudulent activities carried out by the perpetrators.

For fraud mode, we believe that the best taxonomy is by the Association of Certified Fraud Examiners and is known as fraud trees (Uniform Occupational Fraud Classification System) (ACFE 2016).

\subsubsection{Asset Misappropriation}

These deviations include misuse or theft of company assets. Asset misappropriation is the most easily detected fraud because it is tangible or can be calculated.

\subsubsection{Fraudulent Misstatement}

Fraudulent misstatements occur by engineering financial statements to obtain benefits from various parties. Embezzling company assets can also cause the company's financial statements not to be presented in accordance with generally accepted accounting principles and could generate attractive profits (window dressing).

\subsubsection{Corruption}

Corruption is the most difficult fraud to detect because it is usually not carried out by one person but involves another party (collusion). Collaboration can be in the form of abuse of authority, bribery, acceptance of illegal gifts (gratuities), and economic exploitation (economic gratuities)

\subsubsection{Risk Management}

Risk management activities are the complete responsibility of management, whereas the function of internal auditors is to assure management that risk management activities are running effectively and to control risks up to the limits set by management.

Several reasons underlie the paradigm that the function of risk management should collaborate with the internal audit function.

- To link audit plans and company risk assessments, and to share other work products, which are needed to improve coordination in an effort to ensure that the main risks can be dealt with effectively.

- Certain resources are shared to support efficiency. The resources in question include financial, human, and time resources.

- Each other's competencies, roles, and responsibilities can be improved. A consistent communication infrastructure can be provided.

- Strategic risks should be assessed and monitored. A deeper understanding and treatment focused on overcoming strategic risks can be formed. 


\subsubsection{Fraud Risk Management}

According to Lowers and Associates (2015), fraud risk management (FRM) is an approach used by the organization to develop a fraud prevention and detection program as a whole, in an effort to implement risk management.

FRM is applied to every organization in writing, through responsibilities, and through procedures for implementing effective programs. The Board of Trustees and Directors play a role in setting policies related to reporting on information and the performance of each part. The risk of fraud cannot be eliminated but can be minimized by good supervision and early detection.

\subsubsection{Principle 1: Fraud Risk Governance}

The Board of Directors sets organizational goals that meet the needs of stakeholders by establishing good corporate governance, a code of ethics that applies to every employee, relationships between internal and external parties of the company, and adequate internal control. An effective corporate governance process is the basis for FRM. The Board of Directors periodically monitors the effectiveness of FRM activities.

\subsubsection{Principle 2: Fraud Risk Assessment}

Fraud risk assessments are carried out by each company on a regular basis and are tailored to the company's objectives, type of industry, company size, and business complexity. Risk assessment activities can be carried out independently and some must be carried out, such as risk identification, assessing likelihood of occurrence, the significance of assessment, and risk response. Every organization has a defined risk tolerance limit, and fraud risk can be overcome and minimized through risk mitigation activities.

\subsubsection{Principle 3: Fraud Prevention}

Prevention is the first line of defense in minimizing the risk of fraud. Fraud can be prevented by disseminating information to all company entities, from the lower level to the top, regarding FRM programs, including the types of possible fraud.

\subsubsection{Principle 4: Fraud Detection}

The detection of fraud focuses on activities and techniques to ensure that fraud has occurred or is occurring. Every organization is vulnerable to fraud, and detection activities are carried out to ensure the effectiveness of a FRM program that shows that fraud prevention activities have worked effectively. Detection activities can only provide evidence that fraud has occurred or is happening but cannot prevent its occurrence. Detecting fraud requires lower costs than preventing fraud.

\subsubsection{Principle 5: Fraud Investigation and Corrective Actions}

The internal control system is not able to provide a complete guarantee against fraud. The Board of Directors must ensure that the organization develops a system that is fast, competent, and investigative of potential fraud. Through earlier investigative activities and corrective actions, companies can minimize losses, the impact of legal litigation, and damage to their reputations.

Directors and management must have a policy for evaluating each reported indication of fraud. Individuals assigned to the investigation must have full authority over the data needed and the ability to evaluate and provide recommendations for improvements.

\subsubsection{Risk-Based Audit Plans}

The audit planning phase is an initial and important step in producing an efficient and effective audit process and results. According to The Institute of Internal Audits' Audit Performance Standards, "The chief audit executive should establish risk-based plans to determine the priorities of the audit internal activity, consistent with the organization's goals."

\section{RESEARCH METHOD}

This research uses a qualitative descriptive method and a case study approach with a single unit analysis. The data source was primary data and research instruments, such as interviews with the Head of the Internal Audit Unit and the Auditor and related staff, and was directly related to risk evaluation activities related to general audit planning.

\subsection{Research Method}

The qualitative descriptive research in Arikunto (2002) attempts to describe and interpret the conditions of existing relationships, growing opinions, ongoing processes, ongoing consequences, or emerging trends.

This research method was chosen because it was based on the objectives to be achieved, namely, to determine the maturity level of FRM and an adequate fraud risk assessment of the audit planning of the Sub Directorate of the Internal Audit Unit. This study also discusses the appropriate risk assessment method for assessing risk in the audit activities at the Internal Audit Unit. 


\subsection{Data Collection}

In this study, the data were collected as follows.

\subsubsection{Primary Data}

Primary data, including the company budget work plan (RKAP), the annual oversight work program (PKPT), financial statements, company conditions, and opinion sources, were obtained through interviews with company PT X, the unit of analysis.

\subsubsection{Secondary Data}

To support the argument, researchers also use secondary data, including, for example, developments in the transportation industry, government regulations, and others. The secondary data are accessed through public domains such as websites or socialization on the Internet.

\subsection{Technique Analysis (Research Instrument)}

In this study, qualitative research methods consisted of, among others, two main types.

\subsubsection{Observation}

Data analysis techniques carried out in the study began with observations of the PT $\mathrm{X}$ business environment as a whole. These observations were made to determine the existing business processes at the Head Office and the Strategic Business Unit (SBU) of PT X.

\subsubsection{Interview}

Interviews with resource persons were social interactions undertaken to collect valid data and information. In this study, the researchers also conducted interviews with the Head of the Internal Audit Unit and the Auditor and related staff and were directly related to risk evaluation activities in general audit planning.

\subsubsection{Content Analysis}

Researchers analyzed content by critically examining various documents related to the research and checking and analyzing financial statement documents, contract agreements, and interview results from resource persons.

The analytical steps were as follows.

- The maturity level of the FRM program at PT X as a whole was assessed, as well as recommendations for improving maturity. Activities assessed the level of maturity using the FRM Scorecard issued by the ACFE. The assessment was carried out on five FRM principles and by filling in 265 statements using the following evaluation criteria:

Table II. Percentage of Realization of Revenue and BOPO Ratio of SBUS per Semester 2018

\begin{tabular}{|l|l|l|}
\hline Assessment Zone & Score & Information \\
\hline Red & 0 & $\begin{array}{l}\text { Indicates that areas, factors, } \\
\text { or considerations need } \\
\text { substantial strengthening and } \\
\text { enhancement to bring fraud } \\
\text { risk to an acceptable level }\end{array}$ \\
\hline Yellow & 1 & $\begin{array}{l}\text { Indicates that areas, factors, } \\
\text { or considerations need } \\
\text { reinforcement and } \\
\text { improvement to reduce fraud } \\
\text { risk to an acceptable level }\end{array}$ \\
\hline Green & 2 & $\begin{array}{l}\text { Indicates that areas, factors, } \\
\text { or strong considerations and } \\
\text { the risk of fraud have been } \\
\text { reduced, at least to an } \\
\text { acceptable minimum level }\end{array}$ \\
\hline
\end{tabular}

The assessment for each of the FRM scorecard principles issued by the ACFE is as follows.

1) Carry out an assessment of each sub-indicator based on the assessment zone criteria.

2) Find the average value of each indicator (points of focus), where each indicator has a maximum value of 9 .

3) Find the average value of each principle to determine the maturity level of each of the FRM principles, where each principle has a maximum value limit of 9 , which is represented by a color in the 1-9 range of values as follows:

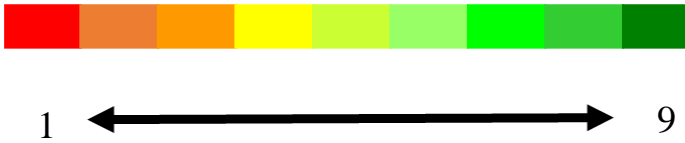

- Fraud risks were identified, fraud risk assessments were conducted, and the priority scale of audit activities was determined.

- A report was prepared on the PKPT based on the results of the fraud risk assessment.

\subsection{Research Object}

This research assesses PT X's overall level of FRM (corporate) and assesses the fraud risk at the PT X Head Office and SBU, which focuses on the community 
transportation service industry in DKI Jakarta, namely, Transbusway SBU. The basis for determining that the Transbusway SBU will be used as the research object is as follows.

Table III. Percentage of Realization of Revenue and BOPO Ratio of SBUS per Semester I 2018 (In Millions of Rupiah)

\begin{tabular}{|l|l|l|l|l|}
\hline & $\begin{array}{l}\text { SBU } \\
\text { TBW }\end{array}$ & $\begin{array}{l}\text { SBU } \\
\text { TJB }\end{array}$ & $\begin{array}{l}\text { SBU } \\
\text { Aslog }\end{array}$ & $\begin{array}{l}\text { SBU } \\
\text { Pemhar }\end{array}$ \\
\hline Revenue & 64.933 & 33.958 & 1.023 & 45.142 \\
\hline Cost & 62.462 & 31.232 & 942 & 22.067 \\
\hline \hline $\begin{array}{l}\text { of } \\
\text { Income }\end{array}$ & $\mathbf{4 4 . 7 6 \%}$ & $\mathbf{2 3 . 4 1 \%}$ & $\mathbf{0 . 7 1 \%}$ & $\mathbf{3 1 . 1 2 \%}$ \\
\hline \hline $\begin{array}{l}\text { BOPO } \\
\text { Ratio }\end{array}$ & $\mathbf{9 6 \%}$ & $\mathbf{9 1 , 9 7 \%}$ & $\mathbf{9 2 , 0 6 \%}$ & $\mathbf{4 8 , 8 8 \%}$ \\
\hline \hline
\end{tabular}

Based on Table III, the Transbusway SBU during the first semester of 2018 contributed revenues of Rp. $64,933,769,821$ or $44.76 \%$ of the company's total revenue. The BOPO ratio of the Transbusway SBU had the highest value among other SBUs, at 96\%. Therefore, the Transbusway SBU was chosen as the object of this research.

In addition to the Transbusway SBU, PT X's Head Office is also the object of this research because it consolidates the company's reports and is the cost center from which all corporate overhead expenses are issued.

\section{ANALYSIS}

\subsection{Fraud Risk Management of PT X}

Fraud risk assessment begins with calculating the maturity of the FRM activities based on the FRM scorecard issued by the ACFE. The results of the assessment of the average FRM maturity score for PT X are as follows.
Table IV. Score Maturity Level of Fraud Risk Management at PT X

\begin{tabular}{|c|l|c|c|c|c|}
\hline No & \multicolumn{1}{|c|}{ Prinsip FRM } & Indikator & Bobot & \multicolumn{2}{|c|}{ Capaian } \\
\hline 1 & Fraud Risk Governance & 6 & 9 & 1,68 & Area \\
\hline 2 & Fraud Risk Assessment & 12 & 9 & 0,43 & $\mathbf{A}$ \\
\hline 3 & $\begin{array}{l}\text { Control Activity } \\
4\end{array}$ & 8 & 9 & 1,60 & $\mathbf{A}$ \\
\hline 5 & $\begin{array}{l}\text { Fraud Investigation and } \\
\text { Corrective Action } \\
\text { Fraud Risk Management } \\
\text { Monitoring }\end{array}$ & 5 & 9 & 4,69 & \\
\hline & \multicolumn{1}{|l|}{ Total } & $\mathbf{3 6}$ & $\mathbf{4 5}$ & $\mathbf{9 , 9 8}$ & $\mathbf{1}$ \\
\hline
\end{tabular}

\subsection{Fraud Risk Assessment of PT X}

Based on the results of the assessment of the maturity of the FRM, FRM at PT X appears to be at the lowest level or in the red area-a score of 2 . This score indicates that the company has the potential to experience high risk. When carrying out internal audits, auditors also need to carry out fraud risk assessments during the planning stage of the audit. These assessments can identify audit areas that have the potential for fraud risk, evaluate the effectiveness of internal control activities carried out by the auditee, and ensure the effectiveness of the planned risk mitigation activities.

The compilation of the fraud risk assessment matrix shows that PT X has 38 fraud schemes spread across the PT X Head Office and Transbusway SBU. Of these 38 fraud schemes and an assessment of the effectiveness of existing control activities, the existing residual risk distribution is listed in Table $\mathrm{V}$.

Table V. Distribution of PT X Risk Score

\begin{tabular}{|l|c|c|c|c|c|c|}
\hline Risk Score & Low & \multicolumn{3}{|c|}{ Medium } & High & \multirow{2}{*}{ Total } \\
\cline { 3 - 7 } \multicolumn{1}{c}{ Auditee } & Risk & To Low & Med & To High & Risk & \\
\hline Kantor Pusat & 1 & 6 & 11 & 2 & 2 & 27 \\
\hline SBU Transbusway & - & - & 6 & 2 & 2 & 11 \\
\hline Total & 1 & 6 & 17 & 10 & 4 & $\mathbf{3 8}$ \\
\hline
\end{tabular}

Based on Table V, the results of the fraud risk assessment matrix indicate that, of the 38 fraud schemes identified, 11 are low risk, 11 are medium risk, and 14 are high risk.

The distribution points of the fraud risk scheme based on risk status, which is a combination of the likelihood level and impact (significant), is indicated in Figure 1. 


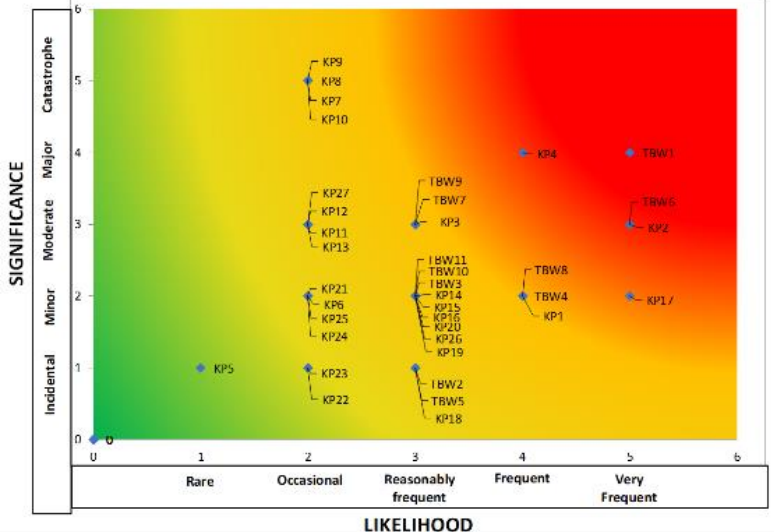

Figure 1. PT X Fraud Risk Map

PT $X$ has four fraudulent schemes in the red zone/area, indicating that the risk status risk is very high and must be followed up with both corrective and preventive actions in the internal control system to avoid recurrence. These risks require the effectiveness of excellent control activities to ensure that the risks are at a level acceptable to management.

Thirty-three fraud risk schemes are in the yellow zone (medium risk) and require that regular and periodic reviews be conducted to ensure that the internal control system runs effectively. One fraud risk scheme is in the green zone (low risk), which requires short monitoring to ensure that the internal control system is effective. The risk in the green zone is noted as not increasing in status.

After understanding the score of each fraud scheme for the two objects of PT X's examination, namely, the Transbusway SBU and Head Office, the ranking of each fraud scheme is based on the value of the risk status to determine the priority when compiling the inspection work program and the number of days of supervision that is appropriate for each fraud scheme. A higher risk status value of the fraud scheme indicates a higher number of supervision days used. This fraud scheme will assist the Internal Audit Unit in determining the number of supervision days required for each fraud scheme that has been identified and compiled by the PKPT. (The Fraud Risk Ranking is included in Appendix 1.)

\subsection{Planning Audit Program}

Audit planning is the first step for the PT X Internal Audit Unit to ensure that the entire audit process runs well and assists the President Director in assessing the level of effectiveness of the company's internal control system. The calculation of the number of supervision days at PT X's Internal Supervision Unit is as follows.
Table VI. Supervision Day Calculation

\begin{tabular}{|lc|}
\hline & Day/People \\
\hline Total Year Day & 365 \\
Total Saturday - Sunday / Year & $(98)$ \\
National Holidays & $(26)$ \\
Leave Day & $(12)$ \\
Permit (2\% Total Day) & $(7)$ \\
\hline Number of working days /Year & $\mathbf{2 2 2}$ \\
\hline Training / Competency Improvement & $(26)$ \\
\hline Number of Supervision Days / People & $\mathbf{1 9 6}$ \\
\hline Number of auditors & 4 \\
\hline Available Supervision Days (OH) & $\mathbf{7 8 4}$ \\
\hline
\end{tabular}

Table IV shows that the number of days of supervision available to prepare the Annual Supervision Work Program of the Sub Directorate of the PT X Internal Supervision Unit for one year is 196 days per person or 784 days with four junior auditors. Such staffing is needed to carry out internal supervision assignments that are divided into two groups of two people each. The supervision day is the maximum supervision day that can be carried out by the PT X Internal Supervisory Unit when conducting surveillance activities for one year at both the PT X Head Office and all SBUs.

Based on the fraud risk assessment matrix that has been prepared and the supervision days set for each fraud risk scheme, each scheme is grouped into several audit activities. Each identified fraud scheme is used as the basis of the object of examination and determination. The scope of the inspection is the Head Office and Transbusway SBU of PT X.

Table VII. Classification of Fraud Risk Schemes, Audit Work, and Supervision Programs of Head Office

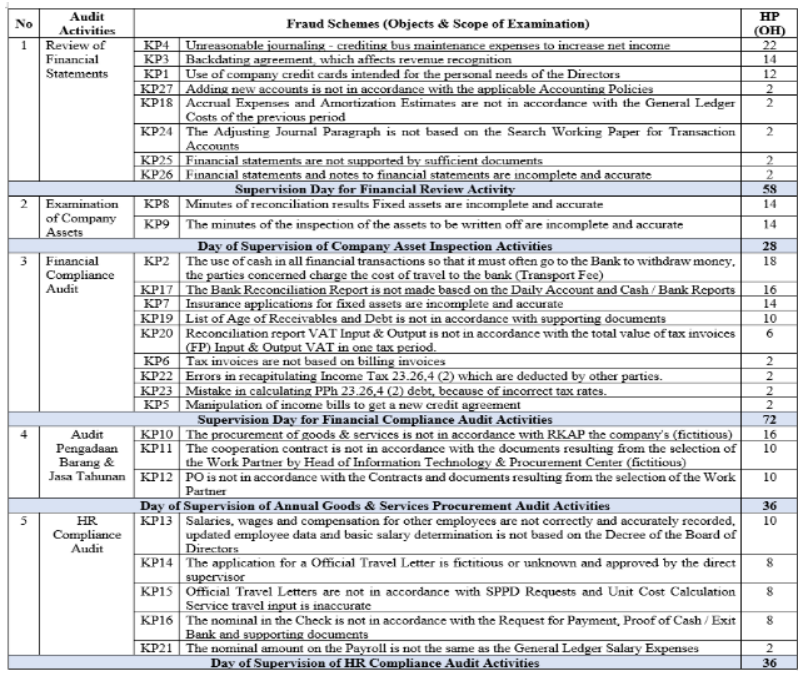


Table VIII. Classification of Fraud Risk Schemes, Audit Work, and Supervision Programs of Transbusway SBU

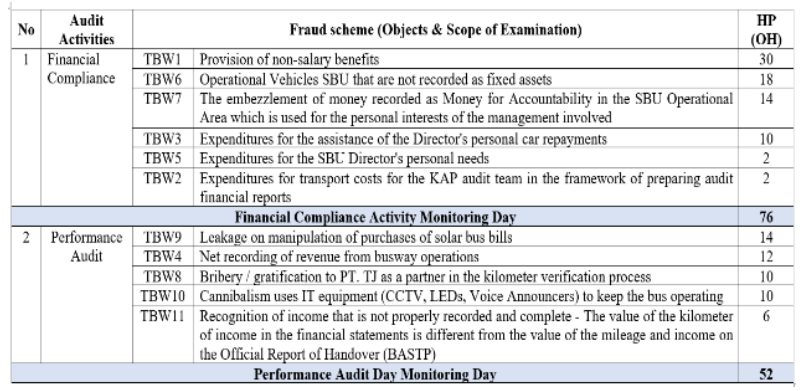

Based on Table VIII, the 38 fraud schemes identified are grouped into five types of internal supervision activities that will be carried out at the PT X Head Office and the two types of internal supervision activities that will be carried out at the Transbusway SBU. The number of days of supervision for each internal supervision activity represents an accumulation of the days of oversight of fraud schemes. The seven types of internal supervision activities are the top priority for the Internal Audit Unit regarding conducting supervision.

When preparing for the Annual Supervision Work Program, considering the frequency of the implementation of each internal supervision activity for one year is also necessary, such that the total number of supervision days for the supervision activities of the Internal Audit Unit will be known for the next year. Determining the basis for the frequency of implementation of each supervision activity depends on the objectives/key performance indicators to be achieved by the company.

The Annual Supervision Work Program for internal supervision activities at PT X's Head Office and Transbusway SBU and as a whole are as follows.

Table IX. Annual Supervision Work Program PT XImplementation of Internal Oversight Activities

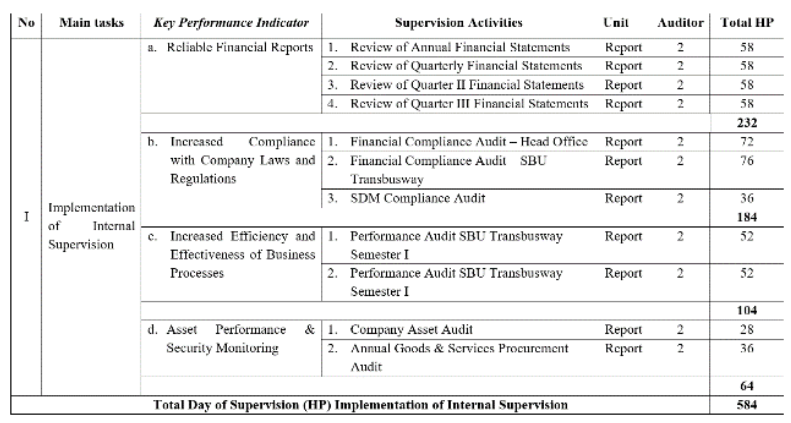

The monitoring days available for one year of audit activities was 784, and 584 days of supervision were used for the Head Office's internal supervision and Transbusway SBU activities. Therefore, 200 days of supervision were remaining. These remaining days of supervision are used to conduct audits of other SBUs by taking into account the results of risk identification. Moreover, if the results of the supervision are still insufficient, PT X should increase the number of auditor personnel or schedule audits during the annual supervisory work program the following year.

\section{CONCLUSIONS}

Based on the results of the research and analysis in this study, the following conclusions are reached.

1. The maturity value of the PT X Risk Management Fraud program, at a total of 9.98 or $22.2 \%$ of the total maturity level needed, depends on its position in the zone/red area, which reflects the maturity level of a well-implemented FRM program and that companies face a high risk of fraud.

2. Fraud involving the Head Office and Transbusway SBU of PT X accounted for 38 risks that might occur, with the residual risk consisting of 11 lowrisk, 11 moderate-risk, and 14 high-risk schemes.

3. A fraud-imposed risk assessment is required for the Internal Audit Unit Sub Directorate to prepare the Annual Work Plan, with a total of 784 supervision days available for monitoring and supervision and 584 days of supervision for 11 internal supervision activities at the Head Office and Transbusway SBU.

\section{ACKNOWLEDGMENTS}

This research was presented at the 4th Asia-Pacific Forum for Research in Social Sciences and Humanities 2019 hosted by the Universitas Indonesia.

\section{REFERENCES}

[1] Ansar, Muhammad. 2013. “Analisis Faktor-Faktor Yang Mempengaruhi Kecurangan Pelaporan Keuangan Pada Perusahaan Publik Di Indonesia”. Artikel Universitas Diponegoro.

[2] Arikunto, Suharsimi. 2002. Metodologi Penelitian. Penerbit PT. Rineka Cipta. pp 126

[3] Association of Certified Fraud Examiners(ACFE). 2016. "The Fraud Triangle". [http://www.acfe.com/fraud-triangle.aspx]

[4] Association of Certified Fraud Examiners(ACFE). 2018. "Fraud Risk Management Tools". [https://www.acfe.com/fraudrisktools/tools.aspx]

[5] Badan Pemeriksa Keuangan Republik Indonesia (BPK RI). 2012. "Pencegahan Tindak Kecurangan". Melalui [http://jdih.bpk.go.id/wpcontent/uploads/ 2012/06/Pencegahan-Tindak- 
Kecurangan.pdf] 21 Agustus 2018 pukul 09.53 WIB.

[6] Crowe Horwarth. 2010. "IIA Practice Guide: Fraud and Internal Audit".

[7] Fitrawansyah. 2014. Fraud \& Auditing. Jakarta: Mitra Wacana Media

[8] Koroy, Tri Ramaraya. 2008."Pendeteksian Kecurangan (Fraud) Laporan Keuangan Oleh Auditor Eksternal'. Jurnal Akuntansi Dan Keuangan, Vol. 10, No. 1,Mei 2008: 22-33.

[9] Lower \& Associates. 2015. "5 Principles of Effective Fraud Risk Management".[https://blog.lowersrisk.com/fraudrisk-management/]

[10] Priantara, Diaz. 2013. Fraud Auditing and Investigation. Jakarta: Mitra Wacana Media.
[11] Roth, James, Best Practices. Value-Added Approaches of Four Innovative Auditing Department.2000. The IIA, 249 Maitland Avenue, Altamonte Springs,

[12] Skousen, C. J., Smith, K. R., \& Wright, C. J. "Detecting and Predicting Financial Statement Fraud: The Effectiveness of the Fraud Triangle and SAS No. 99". Journal of Corporate Governance and Firm Performances, Vol 13,2009: 53-81.

[13] The IIA, AICPA, ACFE. "Managing The Business Risk of Fraud: A Practical Guide"

[14] The Institute of Internal Auditors (The IIA). 2009. "IPPF: Practice Guide Internal Auditing and Fraud".

[15] The Institute of Internal Auditors (The IIA). 2009. "IPPF: Practice Guide Internal Auditing and Fraud". 